\title{
'Between a Rock and a Hard Place': Bulgarian Highly Skilled Migrants' Experiences of External and Internal Stereotypes in the Context of the European Crisis
}

\begin{abstract}
The intensification of intra-European migration has more recently coincided with the negative socio-economic consequences of the European economic crisis. The latter has revitalised dormant national stereotypes, employed into the scapegoating of migrants across Europe. Drawing on multi-sited ethnographic research, this article focuses on young, highly skilled Bulgarian migrants in the UK. Their experiences of internal and external national stereotypes are examined in detail. This article argues that this results in a process of double-sided othering, which has implications upon the identities of young skilled Bulgarians as they employ various strategies to make sense of their migratory choices.
\end{abstract}

Keywords: Bulgarian migrants; highly skilled; stereotypes; European crisis; doublesided othering

The intensification of European integration and the end of the Cold War, have enabled Europeans to study, work and live in other member states, transforming the EU into the epitome of the 'network state' (Castells, 2004). While visa restrictions among the $28 \mathrm{EU}$ member states are now a relic from the (not so distant) past, their non-existence can hardly be proclaimed in a Fukuyamian (1992) manner as the end to intra-European cleavages. Instead, Balibar (2010) argues that borders are more prominent than ever-a claim that becomes more evident in light of the implications of the ongoing European economic crisis. The latter has coincided with high levels of migration both within and outside the EU, thus producing an array of emotional responses with markedly negative connotations both on governmental and local level in many countries (Datta, 2011). Therefore, the economic crisis has tested the core principles of the European Union as across its member-states nationalism(s) have gathered more momentum. This has in 
turn prompted the rebirth of (old) national stereotypes, covered with a thin veneer of Eurosceptic rhetoric.

Correspondingly, Bulgarian migration to the UK is an interesting case. Although not a new phenomenon as Maeva (2010) notes, Bulgarian migratory flows to Britain have significantly intensified since the country, together with Romania, joined the EU in 2007. Notably, the latest data from the Bulgarian National Statistical Institute (BNSI) shows a clear shift in the direction of migratory flows away from 'traditional' destinations such as Spain, Italy and Greece (Club Z, 2015). In 2015, Germany and the UK emerge as top receiving countries for young and highly skilled migrants (Club Z, 2015). This change in the pattern of the newest Bulgarian migratory flows is credited not only to Bulgaria's membership in the EU but also to the impact of the European economic crisis on countries in Southern Europe.

While the literature on the topic is growing (see Chongarova 2010; Author 2015; Ivancheva 2007; Maeva 2010; Markova 2010;), Bulgarian migration to the UK is still less researched in comparison to migratory flows from other Central and Eastern European (hereafter CEE) countries such as Poland, Hungary and Romania (among many, see Csedö 2008; Fox, Moroșanu \& Szillasy 2012; McGhee, Heath and Trevena 2012; Moroșanu 2013a; Moroșanu 2013b; Moroșanu \& Fox 2013; Ryan 2010). Additionally, there are two further problems associated with the knowledge of Bulgarian migration: both public and academic discourses tend to mention Bulgarian migrants briefly either in conjunction with Romanians or under the much broader term 'Eastern European'. Whilst this is largely a reflection of the processes of Eastern enlargement of the EU, such assumptions should nonetheless be treated cautiously for a number of reasons. Firstly, the umbrella term 'Eastern European' is often used as a catch-all phrase to denote all migrant groups originating east of Germany and Austria. 
Undoubtedly, many of the countries in that region share a lot of socio-political and economic similarities, however, the essentialist nature of the term disregards any differences that are often key elements in migrant experiences. Secondly, the term 'Eastern European' has arguably developed negative connotations in the British context in light of strong anti-EU sentiments, as tensions emerge between the freedom of movement and claims for social rights (Cameron, 2014). Thus, the homogenising effect of umbrella terms such as 'Eastern European' in relation to migrants not only emerges as highly contested but it also highlights potential pitfalls in treating different ethnic groups in an essentialist manner.

Therefore, this paper aims to contribute to the literature on newer European migratory flows by focusing on a migrant group that receives comparatively less attention - young, highly skilled Bulgarians in Britain. Based on empirical data gathered through a multi-sited ethnography with Bulgarian university students and young professionals, this paper has three main goals. Firstly, it will explore the external and internal, socially constructed perceptions that young Bulgarians are subjected to both in their host and home societies in the context of the European economic crisis. It will be argued that the participants in the study experience double-sided othering, whereby simultaneous processes of external and internal stereotyping delineate the contours of a temporally- and spatially-bound discursive realm based on constant power renegotiations, which thus impact upon their sense of identity. Secondly, I will analyse the techniques and strategies that the respondents utilise to respond to the dominant stereotypical discourses. While similarities with other CEE migrants will be noted, particular attention will be paid to the differences which outline the problematic nature of the term 'Eastern European'. Ultimately, I will argue that while young Bulgarians in the UK experience double-sided othering, they employ a range of techniques which 
allow them not only to negotiate their identities in that context but also to make sense of their complex realities.

The article begins by theoretically and contextually exploring the nature and characteristics of stereotypes as well as conceptualising the notion of double-sided othering. A brief summary of the research is provided, followed by two empirical sections: the first one will analyse the reactions to and experiences of both external and internal stereotypes, and the second one will focus on counterbalancing strategies and implications for identity. The conclusion summarises the findings and outlines some areas that require further research.

\section{From stereotypes to double-sided othering: theoretical and contextual framework}

The heightened levels of migration within and outside the EU, combined with the effects of the ongoing economic crisis, have not only made the presence of the Other(s) more visible and threatening in host societies but also their absence from the home society- more painful. Thus, arguably, the European economic crisis has become a catalyst for anxiety channelled into various stereotypes towards migrants, which have subjected them to processes of othering in both societies. Othering and stereotypes are not only intrinsically interrelated but their nature and characteristics also impact upon identity formation. Moreover, stereotypes are arguably an integral part of othering and as such - a key element that serves to provide differentiation. Therefore, I will first explore the notion of stereotypes as a way of understanding the basis upon which othering operates. Drawing largely on Jensen (2011), I will trace the relationship between othering, identity and power. Next, the notion of double-sided othering will be conceptualised, arguing that it provides a useful analytical framework for the understanding of migratory experiences. 
The concept will then be contextualised to provide a better understanding of Bulgarian highly skilled migrants' experiences, highlighting the importance of the spatial and temporal conditions within which othering occurs. Finally, some considerations will be mentioned in relation to the problematic nature of the concept of highly skilled migration.

\section{Stereotypes and (double-sided) othering: theoretical postulations}

The ontological foundations of stereotypes can be traced to the 1920 s when Walter Lippmann defined the concept as 'pictures in our heads' (Seiter, 1986, p. 16), thus highlighting the inflexibility of stereotypical perceptions, usually related to images and ideas that are incorrect and rather simplistic. Consequently, stereotypes not only ' $[\ldots]$ erase a person's individuality', but they also '[...] control and constrain people' (Anderson, 2010, p.19). Evidently, the concept involves the establishment of a power relationship, which implicates upon one's identity. Three further key points emerge when scrutinising the concept of the stereotype. Firstly, '....social stereotypes exaggerate and homogenise traits held to be characteristic of particular categories and serve as blanket generalisations for all individuals assigned to such categories' (Pickering, 2001, p. 10). This observation underlines two of the most prominent characteristics of stereotypes - their metonymic and essentialist properties. Thus, national stereotypes not only 'label' groups of people by ascribing characteristics, but they also claim uniformity of 'packaging'. Secondly, again claimed by Pickering, stereotypes dwell in the realm of the politics of representation and as such, they are sensitive to socio-temporal conditions (2001, p. xiv). While the first argument highlights the intricate relationship between stereotypes and identity, the second one points to the need to contextualise the emergence of such perceptions. The terms stereotypes and the Other will be used interchangeably throughout the paper as Pickering (2001) rightfully observes that both 
concepts entail the same processes of categorisation and differentiation (2001, p. xiv). These processes of othering, however, require further clarification.

In that sense, Jensen's (2011) study of ethnic minority men in Denmark is particularly instrumental as it focuses on the potential of othering to describe identity formation, simultaneously highlighting ideas of agency and power. Providing a thorough ontological and epistemological overview of the notion of othering, Jensen affirms its postcolonial roots, noting that Spivak was the first scholar to use it in a systematic way in 1985 to denote a multidimensional process, involving various forms of social differentiation (2011, pp. 64-65). This observation revolves around the idea of inferiority and subordination which emerge as the aimed result of such processes of categorisation. More modern conceptions of the idea continue this line of thought and describe othering as a 'process of differentiation and demarcation, by which the line is drawn between 'us' and 'them' - between the more and the less powerful - and through which social distance is established and maintained' (Lister cited in Jensen, 2011, p. 65). The value of this definition lies in the fact that it highlights the mechanics of identity formation which operate within the process of othering. In that sense, the establishment of an $u s$ and them rhetoric strongly relies on employing a reductionist approach. The latter is achieved through the use of stereotypes, whose homogenising properties play a crucial role in establishing relations of superiority and subordination. Jensen's own definition aims to highlight both the power dynamics and the embeddedness of identity in the process of othering, which entails:

[...] discursive processes by which powerful groups, who may or may not make up a numerical majority, define subordinate groups into existence in a reductionist way which ascribe problematic and/or inferior characteristics to these subordinate groups. Such discursive processes affirm the legitimacy and superiority of the powerful and condition identity formation among the subordinate (italics in original, 2011, p. 65) 
Consequently, the conditionality of identity is located in the power dynamics of the discursive realm of social differentiation. Jensen recognises the need to move away from dichotomous understandings of both othering and identity, which rely solely on binary oppositions (2011, p. 66). Thus, a critical engagement with the process of othering allows the recognition of agency. The latter not only questions the ability of othering to draw the boundaries between superiority and subordination, but it also blurs them by enabling resistance.

Indeed, Jensen's work (2011) raises some valid points with regards to the process of othering such as its nexus with the notions of power and identity. Yet, his analysis remains rather limited due to its narrow contextualisation. In the age of reinvention (Elliott, 2013), characterised by the incessant need to re-formulate and update, the focus is very much on constant change and multiplicity-multiple identities, citizenships, movements, transactions and locations. The latter in particular points to the need of a broader conceptualisation of the processes of othering, one that takes into account various contexts. Consequently, in the case of migration, Anna Triandafyllidou has rightfully argued that: 'In a world organized into nations and national states, th[e] absence from theountry of origin and presence in a foreign one lead to the exclusion of the immigrant from either society' (2006, p. 287). Evidently, to understand migrant experiences, it is important to consider the context and implications of both dominant external stereotyping discourses (those produced by the host society) and the internal ones (those produced by the home society). Therefore, it is necessary to stretch the concept of othering to allow a wider contextualisation. I argue that a particularly useful critical lens is provided by the concept of double-sided othering, which I define in the following way: the simultaneous processes of external and internal stereotyping, which 
delineate the contours of a temporally- and spatially-bound discursive realm, based on constant power renegotiations, which imminently impact upon migrants' identities. Besides the centrality of stereotypes, this definition highlights the dynamic nature of double-sided othering. More importantly, it captures the fluid essence of the power relationships between the Othering and the Othered, which emerge as a result from double-sided othering. Finally, it highlights the importance of contextualising the occurrence of double-sided othering to fully understand migrants' experiences. Thus, the next section will provide an overview of the spatial and temporal conditions that shape the othering that is experienced by young, highly skilled Bulgarian migrants in Britain.

\section{Contextualising double-sided othering}

A closer look at Bulgaria's and Britain's socio- political and economic reality reveals that both countries are entrenched in the legacy of their past, which coupled with the after-effects of the ongoing European crisis, has established migration as a controversial issue.

An analysis of the Bulgarian context reveals complex and rather contradictory perceptions about migration. On the one hand, Bulgarian governments have consistently focused on encouraging migrants' return, thus recognising their importance. Such initiatives include the establishment of the State Agency for Bulgarians Abroad and the adoption of a number of national strategies, the latest of which - the National Migration, Asylum and Integration Strategy (2011- 2020) - features the return of highly skilled migrants as a key priority (OECD, 2012). Yet, on the other hand, there are negative connotations in relation to outward migration which have resurfaced in the Bulgarian public space, prompted by the aftereffects of the European economic crisis. At the beginning of 2013, a series of austerity measures and high electricity prices 
triggered unrest in the country, culminating in the resignation of the centre-right Borisov government (BBC, 2013). The nationwide protests gained new momentum in 2013 under the motto \#DANSwithme ${ }^{1}$. Amidst these turbulent events, another, less favourable image of the migrant came to the fore (Nikolov, 2013). The re- awakened old national stereotypes of emigrating co-nationals, typical of pre-1989 socialist era, which came in the form of a popular anecdote: 'Question: What are the two exits of the crisis in Bulgaria? Answer: Terminal 1 and Terminal 2 of Sofia Airport' (Bozhidarov, 2012). This anecdote has provided the basis of a stereotype of migration as a form of escapism, often interpreted more negatively as national betrayal. Moreover, this discourse has created a rupture between those who stay and those who leave by questioning the identity and belonging of the latter group.

Similarly, Britain is also facing the consequences of its past, which albeit different, reveal several worrying trends. Arguably in a state of "postcolonial melancholia' (Gilroy, 2006), the British discourse is saturated with anxieties about the inability to cope with larger, globalisation processes that imminently erode the power structures of the nation-state. British public discourse has focused on objectifying its anxieties and transforming them into concrete fears, resulting in a resurgence of a defensive national identity. Three specific trends not only illustrate this nationalist turn but have also more recently contributed to the othering of European migrants, and Bulgarians in particular. Firstly, stricter border control and immigration policy have been central to the Coalition government's approach and continue to feature in the current Conservative majority cabinet. Secondly, a shift away from multiculturalism can be observed, which has arguably led to a neo-assimilationist turn in the UK's immigration policy. Such a re- orientation has been defined by '...populist scapegoating of minorities and migrants for the shortcomings of complex social transformations and 
its nostalgic sense of "loss" for a mythical cohesive past...' (Però, 2008, p. 76). Finally, anxieties about social welfare, crime and migration have generated scepticism, camouflaged as anti-EU rhetoric, and forging a vision of the pillars of the nation-state being corroded and hence in need of patriotic protection.

More recently, the removal of labour restrictions for Bulgarian and Romanian nationals in 2014, which coincided with the ongoing economic crisis, strengthened even further anti- EU sentiments. Furthermore, it triggered a negative discourse, reliant on stereotypical representations of Bulgarian migrants. It should be noted, however, that Bulgarians are not the only migrant group in the UK that experiences such stereotypes. In fact, a brief glance at the literature (Csedő 2008; Ryan 2010; Fox, Moroșanu \& Szilassy 2012; Moroșanu 2013a; Moroșanu 2013b; Moroșanu \& Fox 2013) reveals that other CEE migrants are subjected to the same stereotypes, establishing the symbolic boundaries of the Eastern European in Britain as the Other. This image is rigidly framed and cumulatively constructs a poor, badly educated, benefits-driven, potentially dangerous, unskilled migrant. Significantly, this stereotype not only disregards the myriad of migratory paths that people take but it also establishes 'Eastern European' as an umbrella term with markedly negative connotations.

Thus, the analysis of the dominant discourses in both the host and home societies, reveals that two processes of othering are occurring simultaneously, subjecting migrants to both internal and external stereotypes.

\section{Defining highly skilled}

Despite the proliferation of typologies, it has become increasingly difficult to pin down who can be categorised as a highly skilled migrant (Csedő 2008). Given the focus of this study, it is necessary to clarify the use of this term. 
The British government has adopted a comprehensive list of criteria within its Points-Based Immigration System where factors such as age, education, work experience and earnings tilt the scales either way (UKBA, 2011, p.2). Within academia, however, a greater diversity can be observed which contributes to the general confusion regarding the term. While Salt (1992) is primarily concerned with people within certain occupations (professional, managerial and technical migrants) who accept job positions adequately matching their skills, Iredale (2001) strives to escape this narrow approach by developing a rather comprehensive typology to accommodate various migratory patterns. Ultimately, she also fails to recognise that being a highly skilled migrant does not represent a given status but rather an outcome of a dynamic relationship between the employer and the employee in migratory contexts. In that sense, Csedö's (2008) study adequately differentiates between highly skilled and highly qualified migrants, where the first group possesses not only general (level of education) and specific (work experience) skills but are also able to successfully negotiate their credentials in migratory contexts. Additionally, Wolfeil (2009), Chongarova (2010) and Iredale (2001) highlight that students are a subset group of privileged migrants. Drawing on Csedő (2008), I adopt a broad definition, whereby both university students and professionals are considered as highly skilled migrants due to the fact that in both cases they have successfully managed to negotiate their skills in the migratory context. With that in mind, the next section discusses the 'mechanics' underpinning this research.

\section{The study}

The study is a multi-sited ethnography (Marcus, 1995) that incorporates offline and online participant observation as well as semi- structured interviews. Such a research design not only enables the researcher to 'follow' their participants and to get an indepth knowledge of their experiences, but it also takes into account the specificities of 
different locations (Elwood \& Martin, 2000). The latter is crucial, given the strong regional differences in Britain.

Researching highly skilled Bulgarian migrants in the UK represents a rather challenging task. Like their French counterparts (Ryan \& Mulholland, 2014, p. 588), the lack of a single systematic mechanism accounting for their number in Britain renders them invisible. While the Office for National Statistics claims that in July 2012 there were 47,000 Bulgarian-born people in the UK (BBC 2014), the National Institute for Economic and Social Research asserts that their number was 26,000 in 2013 (Rolfe et al., 2013, p. 21). The demonstrated discrepancy in data not only reflects the unreliability of statistics but it also highlights further problems associated with the lack of information regarding Bulgarian migrants' geographical location and their status in relation to skills. As it will be demonstrated below, this required the use of a range of sampling techniques.

The sample(s) of the study consist(s) of both students and young professionals in order to capture the wide spectrum of young Bulgarian skilled migration. Drawing on Csedő (2008), Chongarova (2010) and Rolfe et al. (2013), the sample criteria focused on Bulgarian nationals, aged between 18 and 35 who were either in the process of obtaining a higher education degree or had already received one, and were living in the UK at the time of the study. In accordance with Csedö (2008), the participants who were students and had a low skilled part-time job to support their studies were still considered as 'highly skilled' because their primary goal for migrating to Britain was not to join the low skilled labour force but to receive education, and that is a position which requires one's negotiation of skills in the host society context.

I utilised purposive sampling to ensure a sufficient range of informants from key demographic characteristics: age, gender, occupation, UK location and length of 
stay. As can be seen in Appendix 1, I have interviewed 37 participants, aged between 19 and 32 years old: 18 male and 19 female, of which 16 were young professionals and 21 - students, based in 6 regions in the UK.

In addition to interviewing participants, I have spent extended periods of time with them, occasionally attending social events and celebrations with them. Moreover, the majority of them have either befriended me on Facebook and/or added me to student and young professionals' groups they belong to. This imminently raises ethical implications, which I addressed by adopting a reflexive approach (Aull Davies, 2002) and treating consent as a constantly negotiated relationship rather than a one-off given permission. Thus, both online and offline participant observation has allowed me to get more in-depth knowledge about respondents' everyday lives, where social media serves as a key factor for communication in both home and host societies, adjustment to life in the UK and maintaining social networks. I was particularly interested in exploring how participants respond to dominant stereotypical discourses in both the host and home society, and what the implications are of this process of double-sided othering.

A thematic analysis was carried out whereby codes were firstly generated inductively, followed by a '...deductive re-examination of the data, to produce rigorous and analytically informed findings' (Ryan \& Mulholland, 2014, p. 589). This has produced rich data whereby various techniques to manage national stereotypes as well as their implications for participants' identities have emerged as prominent themes. The latter is considered in detail in the next section.

\section{Reactions to and experiences of double-sided othering}

This section explores whether and how double-sided othering affects the experiences of young skilled Bulgarian migrants in the UK. Both external and internal stereotypes are considered. More specifically, the data will highlight the problematic nature of the term 
'Eastern European' and the importance of location in the case of external stereotypes as well as the deepening rift between stayers and leavers in the case of internal categorisations.

\section{External stereotypes}

Unsurprisingly, initially many of my participants respond that despite being aware of external stereotypes, they have not been affected by them. This could be explained by the fact that unlike Datta's (2011) 'last hired and first fired' respondents, young skilled Bulgarians tend to find themselves in less precarious positions both while at university and at the workplace. In fact, 20- year old student Maria $^{2}$ shares that she has experienced a lot of positive attitude precisely because she is Bulgarian. Others, such as young professional Vasil demonstrate a very understanding attitude toward external othering: 'I have not been affected directly. [...], I do think however that this [othering] is because their country, Britain, has had a lot of negative experience with immigration'. While such a rational reaction is demonstrated by the majority of respondents, their reasoning varies. While Maria cites the power of the media to frame discourses, marketing specialist Kalina sarcastically remarks: 'They envy us! Because we are so pretty and smart, they envy us for being so poor!' However, the data highlights that while reactions tend to be more rational, actual daily experiences point to either subtle (perception of discrimination/ condescending attitude) or direct effects (experiences of discrimination). In fact, a prevalence of the first over the second can be noticed.

For example, 23-year-old professional Dessie shares that external stereotypes about foreigners, and Bulgarians in particular, had initially established an expectation of discrimination, which resulted in low self-esteem. This feeling was additionally strengthened by one of her friends who kept joking about her accent. Interestingly, when Dessie confronted her friend, he justified his actions as a way for him to manage 
his own self-esteem as he felt intimidated by her achievements. Evidently, discourses of othering, whether or not they result in different treatment, produce a range of sensitive reactions, often compromising the emotional well-being of those subjected to them.

Bilyana's story further illustrates that point. She came to the UK as an undergraduate student through the Seasonal Agricultural Worker's Scheme to work on a broccoli farm in Scotland, and save money to obtain a British master's degree. It took her a few years to achieve this, during which she worked on a mushroom farm in Southern England, bartended in a working men's club in London and had other low skilled positions until she completed her degree and secured a graduate scheme position. With the increasingly negative portrayal of Bulgarians in the media, she found herself in situations where attitudes toward her changed as soon as she mentioned her nationality.

This has strengthened her own perception of experiencing condescending attitude:

Bilyana and I decided to conduct the interview in a newly opened café. Immersed in our conversation, we did not notice that they had a poetry reading event that day, so it was not until it had already begun that we realised what was going on. We lowered our voices and I quickly asked my final questions. Upon exiting the café, we had the following conversation:

Bilyana: 'You probably didn't notice but the lady sat behind you was giving us nasty looks'.

Researcher: 'Really?'

Bilyana: 'Yes! It was because we were speaking in Bulgarian. Such a good example of condescending attitude!'

Researcher: 'Did you not think that was because we were disrupting their event and not because we were speaking a foreign language?'

Bilyana: 'Maybe, but it felt like it was because we were speaking a different language'. (Memo, March 21, 2014)

Given the context of this everyday situation, it is very likely that the annoyance of the lady in the café was provoked by our lack of consideration for the ongoing poetry event. Nonetheless, Bilyana interpreted it as an act of condescending attitude rather than a reaction provoked by our socially inadequate behaviour. This episode clearly 
demonstrates how the negative macro context that participants live in has increased their sensitivity to othering. The realm of the everyday thus transforms into an arena where social interactions in a public space blur the line between perceptions of othering and actual discrimination.

Although less, my participants reported a few experiences of actual discriminatory attitude. Interestingly, they do not interpret it as resulting from being members of a specific national group. Rather, they view it as stigmatization associated with the socially constructed image of the migrant as a foreigner. While Bulgarians remain relatively 'invisible' in terms of phenotypic markers, the most obvious difference that becomes a tool for othering is their accent. Emanuela, reflecting upon the process of looking for a job, mentions that a few potential employers terminated scheduled phone interviews as soon as they heard her accent. Once she was told by a prospective employer that 'there is no point in continuing this interview. The experience that you have is great but my clients are not gonna be impressed by the fact that you're Eastern European'. This clearly highlights how in social contexts 'Eastern European' is used as a catch-all phrase. Furthermore, young professional Ivan adds: 'Actually, I think that Eastern European is used as a term with a derogatory meaning, which is not right'. Therefore, many of my respondents claim that the term is a metonymical referral with negative overtones to a very large group of people with different cultural, social and national backgrounds.

Furthermore, the data accentuates the importance of the spatial dimensions of external stereotypes. For example, while working at large company in the Midlands, Emanuela recalls a particularly distressing case when one of her work colleagues repeatedly asked her to pronounce words containing the letter ' $r$ '. Imitating her accent, he commented: 'You [migrants] all need to learn how to speak with a normal accent 
'cos you have chosen to come here [...]' (participant's emphasis). Emanuela recollects that her manager excused her colleague's behaviour with the fact that as a Northerner he has had limited communication with foreigners. In this particular instance, regional differences in levels of diversity appear as factors influencing the attitude towards foreigners, even if the latter are highly skilled. Bilyana makes a similar point reminiscing about living and working in Southern England. In contrast, London is described by 23-year-old Boris as a 'transmission centre' and a 'hub', where people not only 'come for a while and leave' but also where one experiences a lot of diversity, which results in less visibility and exposure to stereotypes. In line with Barker (2015), the Scottish context appears as more migrant-friendly as my participants describe the locals as more 'warm- hearted than the English'. Final year student Marko explains that 'Bulgarian students in Scotland as European citizens are treated equally to Scottish students and are not required to pay tuition fees ${ }^{3}$. This not only makes them feel welcome but it also diminishes the symbolic boundaries between them and locals.

Evidently, the socio- political regional differences, combined with ascribed personality traits of the locals, emerge as key factors in positive attitudes towards migrants in Scotland. Regardless, students who both study and work part-time appear more likely to experience condescending attitudes. An example is provided by Delyan, an undergraduate student who works part-time at Subway, where on a number of occasions customers have made derogatory comments upon hearing his accent. Thus, migrants' skills and status are automatically judged on the basis of a setting, where people can expect to find low skilled labour.

Consequently, the data reveals that external stereotypes have increased the respondents' sensitivity toward differential treatment. While the cases of perceived 
outweigh those of actual discrimination, the findings point out that location in the form of specific contexts plays a key role in determining the Other.

\section{Internal stereotypes}

Interestingly, while external stereotypes generate more emotional reactions, the internal ones were categorically dismissed on the basis of narrow-minded thinking and lack of understanding of the difficulties that one encounters in migration. With regards to the latter, Ivan contends:

Firstly, I can bet anyone who lives in Bulgaria that they couldn't do what many here have experienced, and secondly, it's not as easy as they think. I mean, most of my good friends here have not only studied hard but they have also had two jobs while doing so to support themselves.

This demonstrates that negative internal stereotypes are not only dismissed on the basis of lack of knowledge but also that the experience of migration is seen as a rite of passage. To leave Bulgaria, for many of my respondents such as Kalina and Ivan, requires courage, determination and strong will. Furthermore, as Ivan's remark suggests, while migrants are being othered, they themselves rely on sweeping generalisations to respond to dominant discourses. Investment banker Paula goes even further when she contends: 'There are a few quality people of those who have decided to stay in Bulgaria, I think. Those who have stayed are those who for some reason could not leave' (my emphasis). Evidently, internal stereotypes reveal that othering is twosided, simultaneously highlighting the presence of a strong cleavage between stayers and leavers.

Moreover, similar to Moroșanu's (2013a, 2013b) account of the experiences of Romanians, internal stereotypes lead to feelings of estrangement upon return to the home country. Such is the case with Svetla when she goes back to Bulgaria. Svetla is a $\mathrm{PhD}$ student who is divorced and has a 6-year old daughter. She recalls a situation when 
after spending only a year in England, upon going back to her hometown a friend told her that she spoke like an 'English girl' and with an accent. Such comments question the respondents' national identity and belonging, subjecting them to processes of othering. On another occasion, 32- year old young professional Teodora recollects her frustration at the impossibility of buying a return ticket for the metro, which is a standard practice in London and anywhere else. The cashier's response of - 'You can do that when you go back in London. Now you are in Bulgaria'- not only made Teodora feel judged but also out of place. Furthermore, this story reveals that everyday situations upon return often provide contexts which exacerbate the division between migrants and non-migrants, often generating stereotypes on both sides.

Comparatively, the participants' reactions to and experiences of othering produced by the home society are less varied than attitudes towards similar processes in the host society. Those two simultaneously processes nonetheless affect young Bulgarian's experiences of migration. Moreover, the process of double-sided othering leads to a number of reactive, counterbalancing strategies which allow the Othered to renegotiate and reverse the power dynamics of 'us' and 'them'. As the section below will demonstrate, this ultimately affects identity formation.

\section{Double-sided othering: counterbalancing strategies and implications for identity}

The analysis of the effects that double-sided othering has on young Bulgarian highly skilled migrants Britain, reveals four key strategies that they employ to respond to stereotypes: assimilationist, segregationist, integrationist and proactive approaches. Consequently, while the first part of this section will consider each of the strategies in turn, the second one will focus upon the implications they have had upon young 
Bulgarian migrants' identities, arguing for a tendency toward particularism and situationalism.

\section{Strategies}

Those of the respondents who utilise an assimilationist strategy to counterbalance double-sided othering focus their efforts on adopting elements of the host society culture. This often entails an attempt to diminish obvious markers such as accent, cultural practices or name, which increase visibility and thus could potentially serve as the basis of othering. Svetla relies on such an assimilationist strategy, trying to avoid potentially being othered on the basis of being a foreigner. Thus, she considers her marriage to Rob as a turning point:

The biggest difference I saw was when my [last] name changed from Petrova to Jones. People think you are from here [...] You are not so much a foreigner [...] As far as jobs are concerned, the name makes a big difference.

Consequently, for Svetla the change of a family name has meant mostly an opportunity to be treated equally. Moreover, it has helped her to camouflage her background, thus protecting her from being exposed to various processes of othering. This is also the reason why even after getting divorced, she has decided to retain her ex- husband's family name. This assimilationist strategy allows her to blend in without being judged on the basis of her nationality.

Another technique for counterbalancing double-sided othering that emerges from my data is segregation. It entails a practice whereby some of the respondents try to actively disengage from compatriots in order to avoid stereotypes attached to this migrant group in Britain. A similar practice is observed by Ryan (2010) in the case of Polish migrants in London. Young highly skilled Bulgarians, however, drawing on their professional background, predominantly disassociate their migration experiences on the 
basis of class. This leads marketing specialist Kalina to remark that she does not feel as a migrant as this is: ' $[\ldots]$ someone who has come here in order to stay here...to have a better life... but a bit lower class in general. Someone who works at Tescos'. Her disengagement with compatriots employed in the service sector is evident in the following episode:

I was visiting Kalina and she suggested that we grab lunch from the local Turkish takeaway in [borough in London]. We were speaking in Bulgarian while deciding what to order and then the girl at the till, also Bulgarian, introduced herself. While were waiting for our order, the girl came over to ask us whether we knew any other Bulgarians who were looking for a job. Kalina quickly replied: 'I already have a job and I don't know any other Bulgarians'. Interestingly, her body language also changed, signifying annoyance with the girl's presence. When we left I asked Kalina why she was so reserved towards the girl, which she explained in the following way: 'I just don't like it when people just come over like that and act as if they know you just because you are both Bulgarian. I don't want anything to do with those people'. (Memo, August, 2014).

The fact that Kalina felt very uncomfortable in this situation, combined with the effort of establishing a boundary, signifies that membership in the same ethnic group does not presuppose similarities (Moroșanu, 2013a). Right on the contrary, this segregationist strategy in relation to co-nationals suggests that the processes of othering affect negatively inter-ethnic cohesion, accentuating class divisions.

Furthermore, such a segregationist approach can be also observed in relation to other CEE migrants, tarred by the same stereotypical social constructions. In an attempt to disassociate themselves, many of the respondents draw on cultural markers and everyday practices to emphasise differences. Ivan, for example, remarks:

We have more in common with Greeks and Turks than with Poles and Lithuanians...despite language [similarities]. On the whole, there is a huge difference. [...]. I usually accentuate the fact that Bulgaria is not in Eastern Europe, it is in South-eastern Europe, and as a result we are quite different to other [CEE] nations [...]. 
He goes further to point out a range of reasons that outline this divide: from differences in the climate, through the fact that 'we drink more like the French and Italian' to the fact that Bulgarians are much closer to Turks, Serbs and Macedonians in terms of mentality than Romanians and Lithuanians. Notably, all these reasons serve to counterbalance metonymical representations of 'Eastern Europeans'. Similarly, Emanuela emotionally exclaims: 'I hate it when people say I am Eastern European. I am from the Balkans!', stating that the difference between the two lies within the fact that Balkan people have 'more passion' and 'a great sense of humour'. This suggests the presence of a regional ethno-centrism, which is accentuated by dominant external stereotypes. Moreover, such an approach serves to not only to counterbalance negative discourses but it also helps young Bulgarians to make sense of a complex reality.

With regards to external stereotypes, another strategy to not only manage the effects of social categorisations but also to counterbalance them is the integrationist approach. Unlike the other two strategies, respondents who adopt this approach neither diminish their cultural background nor disassociate themselves from other, they accept both. Instead, they rely on diminishing stereotypes through openly talking about them in the form of jokes with friends and colleagues. This strategy allows participants such as Nayden, Ivan, Boris and Ralitsa to negotiate their place in the host society environment.

Finally, a number of participants employ proactive approaches that aim to not only promote the rich cultural heritage of Bulgaria but also to counterbalance both internal and external stereotypes. With regards to the latter, this strategy involves a conscious effort to demonstrate positive personal characteristics. A prominent example of this practise is sociology student Kamelia, who shares: '[...] I always explicitly say that I am Bulgarian. I almost view it as a cause. [...] I try to be the best version of myself and of a Bulgarian that someone can meet'. Evidently, in her case, there is a 
conscious and purposeful effort to present herself positively. Moreover, for Kamelia, Maria, Simeon, Nelly and Maria this proactive approach involves being an 'Ambassador of Bulgaria' through sharing meals and national celebrations with their international friends. The practice of raising awareness of the cultural richness of Bulgarian traditions aims to counterbalance the overall negative British media rhetoric in relation to the country and its nationals. The process of othering in the host society has its emotional implications - shame - upon the experiences of my respondents. Consequently, highlighting one's nationality and focusing specifically on the positives serves as a way to promote a better image of the entire migrant group.

Finally, another proactive strategy, specifically directed toward internal stereotypes involves justifying migration as necessary step towards enriching one's personal skills, which will then enable return to the host society to make a difference. Young professional Boyan is the most prominent example. He keeps a diary where he writes down all ideas that he has come across or that have occurred to him, and spends time thinking about how they can be modified and implemented in Bulgaria. Similarly, Politics student Delyan contends: 'My goal is [...] to get the best possible education and one day to apply it in such a way which will benefit my people'. Evidently, the improvement of the self is a necessary step in the achievement of making a difference. What makes an impression in Delyan's speech is the use of a possessive pronoun "my" in relation to his fellow countrymen. This alludes not only to a strong sense of national belonging but also to an understanding of his educational choice almost as a cause - as a mission in the pursuit of counterbalancing internal stereotypes.

Overall, the respondents rely on a wide range of techniques that can be used either interchangeably or in conjunction with each other to react to double-sided othering. While the assimilationist, segregationist, integrationist and proactive strategies 
do not exhaust the list of possible ways that young skilled Bulgarians in the UK employ to manage stereotypes, they nonetheless highlight some prominent tendencies.

\section{'Between a rock and a hard place': implications on identity}

The quest into understanding young highly skilled Bulgarians' experiences of internal and external national stereotypes reveals a complex puzzle of techniques and approaches that ultimately allow them to negotiate their place 'between a rock and a hard place'. These varied techniques not only renegotiate the power imbalance created by experiencing double-sided othering, but also affect the identities of the respondents.

The analysis of the four strategies reveals not only the multiplicity of identities that respondents draw on but also their situational character. Consequently, an assimilationist approach emerges as quite helpful in avoiding stereotypes and serves mostly as a prevention measure. As such, this strategy downplays national identity and draws on markers developed through a prolonged period of living, working and studying in Britain. In contrast, the proactive technique aims to tackle directly stereotypes, while the integrationist one accepts and dismisses them. In doing so, the first approach accentuates national identity, while the second one relies on one's skills to negotiate a place in the host society.

Furthermore, in the context of double-sided othering a certain particularistic tendency can be observed. The segregationist strategy is the approach that starkly highlights this trend, which is directed toward co-nationals and other CEE migrant groups. With regards to the first, Kalina and Ivan draw on their professional identity and their ability to negotiate their highly skilled status to differentiate themselves from low skilled compatriots. This suggests that Bulgarians in the UK are not a homogenous 
group and that as Moroșanu (2013a, 2013b) contends ethnic markers do not automatically lead to a sense of shared experiences and understanding. Furthermore, the segregationist strategy suggests that participants exhibit particularism, underpinned by ethno-centrism. By actively highlighting differences with other CEE nations, young Bulgarians point to the conclusion that 'Eastern European' is a rather problematic term that has negative connotations in the British context. Furthermore, the phrase is often viewed as a metonymical representation that erases specific socio-cultural and political factors that delineate national identities.

The thus discussed implications upon the respondents' identities highlight once again the importance of considering how internal and external stereotypes affect and questions migrants' choices. Hence, the exploration of double-sided othering, contextualised in light of the ongoing European crisis offers the chance to understand more deeply the experiences of migrants and their daily lives.

\section{Conclusion}

In a time of high levels of migration both within and outside the EU, combined with the effects of the ongoing economic crisis, fear and anxiety have questioned the unity of Europe. The sense of insecurity has permeated all levels of society from the supranational to the local- resulting in a multiplication and personalisation of the presence of a 'crisis'. In such a context, it has become increasingly important to achieve some sense of stability through clearly delineating and defining the boundaries of the Self through the image of the Other. Imminently, this has not only made the choice to migrate more problematic but it has also brought to the fore the powerful presence of processes of othering. 
Consequently, this paper has aimed to explore young, highly skilled Bulgarians' migratory experiences in the context of the presence of dominant stereotypical discourses. By theoretically exploring such discourses and their relationship with stereotypes, power and identity, it has been argued that the notion of othering needs to be stretched further in order to take into account migrants' double embeddedness in both host and home society contexts. In that sense, the paper has conceptualised the idea of double-sided othering, arguing that it serves as a useful analytical framework that captures the temporal and spatial conditionality of simultaneously operating processes of internal and external stereotyping, which shape the contours of a discursive realm whereby power is constantly renegotiated and identities - redefined.

Applying that analytical approach to a relatively less researched group of migrants in the UK, this article has focused on the case of young, highly skilled Bulgarians. By adopting a broad definition of the term highly skilled, the analysis has included both young professionals and university students who live, work and/ study in Britain. As such, the article has presented a snapshot of a specific group of people at a specific time. While this has not allowed generalisability, it has nonetheless highlighted some responses to and strategies to counterbalance double-sided othering as well as its implications for the participants' sense of identity. Interestingly, the participants' accounts reveal that more varied reactions to and experiences of external stereotypes than those which have occurred as a result of internal ones. This can be explained by the fact the participants in the study live in Britain and only go back to Bulgarian occasionally, which makes them more likely to be exposed to external, rather than internal stereotypes. Furthermore, while the participants initially reported the lack of effect of external stereotypes upon their daily lives, the further exploration of their experiences nonetheless revealed a more nuanced element of othering. This involved 
the presence of a strong perception and expectation of being subjected to discriminatory and/or condescending attitude over actual discrimination, which were highly dependent on location and the specificities of regional contexts. With regards to internal stereotypes, their effects were experiences either upon return or through interaction with family and friends. Regardless of the actual context and of the fact that such discourses of othering were automatically dismissed, their nature and characteristics left Bulgarian highly skilled migrants feeling out of place, thus also questioning their identities.

Furthermore, the exploration of the process of double-sided othering in the case of young, highly skilled Bulgarian in Britain has revealed that they employ four distinct strategies that aim to respond to and renegotiate the power imbalance created by stereotypes. While the assimilationist and segregationist techniques aim to avoid the consequences of being othered, the integrationist and proactive approaches tackle it directly. Consequently, this process of reversing the power dynamics of double-sided othering affects the respondents' identities, highlighting a tendency towards particularism.

Finally, the paper has highlighted the necessity to treat catch-all labels such as 'Eastern European' critically. While migrants who come from that region imminently share many characteristics, they also have a lot of differences. Therefore, future research agendas should explore this further as well as the nature, characteristics and implications of the process of double-sided othering for other migrant groups.

\section{Acknowledgements}

I would like to express my gratitude to Dr Aline Sierp and Dr Christian Karner for giving me the opportunity to contribute to this Special Issue and for their constructive criticism and 
support. I am also indebted to the Editor of National Identities, Professor David Kaplan, three anonymous peer reviewers, Emma Craddock and Helen Creswick for their helpful comments on earlier drafts. I wish to thank all my participants for their time and contribution to this research.

\section{References}

Anderson, K. J. (2010). Benign Bigotry: The Psychology of Subtle Prejudice. Cambridge: Cambridge University Press.

Aull Davies, C. (2002). Reflexive Ethnography: A Guide to Searching Selves and Others. London: Routledge.

Balibar, E. (2010). At the borders of citizenship: a democracy in translation?, European Journal of Social Theory, 13 ( 3), 315- 322.

Barker, F. (2015). Nationalism, Identity, and the Governance of Diversity: Old Politics, New Arrivals. Basingstoke: Palgrave Macmillan.

Bauman, Z. (2007). Liquid Fear: Living in an Age of Uncertainty. Cambridge: Polity Press.

BBC. (2013). Bulgaria's government to resign, PM Boyko Borisov says. [BBC News Europe online]. Retrieved from http://www.bbc.co.uk/news/world-europe-21516658.

BBC. (2014a). Q\&A: Bulgarian and Romanian immigration. [BBC News Politics online]. Retrieved from http://www.bbc.co.uk/news/uk-politics-21523319.

BBC. (2014b). David Cameron's EU speech: full text. [BBC News Politics online]. Retrieved from: http://www.bbc.co.uk/news/uk-politics-30250299.

Bozhidarov, D. (2012). Samo dva izhoda ot krizata- terminal 1 I terminal 2, [Only two exits from the crisis: terminal 1 and terminal 2], Webcafe [online]. Retrieved from http://www.webcafe.bg/id_1342784288.

Castells, M. (2004). The Power of Identity. Oxford: Blackwell Publishing.

Chongarova, I. (2010). Bulgarskite studenti v London. Obrazovatelni strategii $i$ migratsionni modeli: Sadarzhatelen otchet po proekt za sabatichna godina, [The Bulgarian Students in London. Educational Strategies and Migration Pattern: Study 
Leave Report. Retrieved from http://files.slovo.uni-plovdiv.bg/clic/bulgarian-studentsPRINT.pdf.

Club Z. (2015). Nashite emigranti veche smeniha posokata. Veche ne otivat v Ispania I Italia, [Our emigrants have changed direction. They no longer go to Spain and Italy], Club Z Politics [online]. Retrieved from http://clubz.bg/27478nashite_emigranti_smeniha_posokata_veche_ne_otivat_v_ispaniq_i_italiq_.

Craven, N. and Arbuthnott, G. (2013). Thousands of Bulgarians and Romanians 'plan to flood the UK in 2014' as employment restrictions relax. Available on The Mail [online]. Retrieved from http://www.dailymail.co.uk/news/article-2268952/ThousandsBulgarians-Romanians-plan-flood-UK-2014-employment-restrictions-relax.html.

Csedő, K. (2008). Negotiating skills in the global city: Hungarian and Romanian professionals and graduates in London, Journal for Ethnic and Migration Studies, 34 (5), 803- 823.

Culliford, G. (2013). Next stop UK: Romanians and Bulgarians are queuing up for handout Britain', The Sun [online]. Retrieved from http://www.thesun.co.uk/sol/homepage/news/4776276/Romanians-Bulgarians-arequeueing-up-for-handout-Britain.html.

Datta, K. (2011). Last hired and first fired? The impact of the economic downturn on low- paid Bulgarian migrant workers in London, Journal of International Development, 23 (4), 565- 582.

Delanty, G. (2008). Fear of Others: social exclusion and the European crisis of solidarity, Social Policy and Administration, 42 (6), 676- 690.

Eaton, G. (2013). UKIP stokes fear over Bulgarian and Romanian immigration with countdown clock. Available on The NewStatesman [online]. Retrieved from http://www.newstatesman.com/politics/2013/01/ukip-stokes-fear-over-bulgarian-andromanian-immigration-countdown-clock.

Elwood, S. A. \& Martin, D. G. (2000). "Placing” interviews: location and scales of power in qualitative research, The Professional Geographer, 52 (4), 649-657.

Fox, J. E., Moroşanu, L. and Szilassy, E. (2012). The Racialization of the New European Migration to the UK, Sociology, 46 (4), 680-695.

Fukuyama, F. (1992). The End of History and the Last Man. London: Hamish Hamilton. Gilroy, P. (2006). Multiculture in times of war, Critical Quarterly, 48 (4), 27- 45.

Iredale, R. (2001). The migration of professionals: theories and typologies, International Migration, 39 (5), 7- 13. 
Ivancheva, M. (2007). Strawberry fields forever? Romanian and Bulgarian student workers in the UK, Focaal-European Journal of Anthropology, 49, 110-117.

Jensen, S. Q. (2011). Othering, identity formation and agency, Qualitative Studies, 2 (2), 63-78.

Maeva, M. (2010). Organizations and institutions of Bulgarian emigration in the UK, in: Karamihova, M. (ed.) European dimensions of culture and history on the Balkans (276291). Sofia: Paradigma.

Marcus, G. E. (1995). The Emergence of Multi- Sited Ethnography, Annual Review of Anthropology, 24, 95- 117.

Markova, E. (2010). Emigratsiata na bulgari vuv Velikobritania: London I Brighton, v Tendentsii v Transgranichnata Migratsia na Rabotna Sila I Svobodnoto Dvizhenie na Hora- Efekti za Bulgaria [Bulgarian emigration to Britain: London and Brighton. In Tendencies of the Transnational Migration of Labour Power and Free Movement of People- Effects on Bulgaria ] (129- 161). Sofia: Open Society Institute.

McGhee, D. Heath, S. and Trevena, P. (2012). Dignity, happiness and being able to live a 'normal' life in the UK - an examination of post-accession Polish migrants' transnational autobiographical fields, Social Identities: Journal for the Study of Race, National and Culture, 711-727.

Medrano, J. D. \& Gutiérrez, P. (2001). Nested identities: national and European identity in Spain, Ethnic and Racial Studies, 24 (5), 753- 778.

Moroșanu, L. (2013a). 'We all eat the same bread': the roots and limits of cosmopolitan bridging ties developed by Romanians in London, Ethnic and Racial Studies, 36 (12), 2160-2181.

Moroșanu, L. (2013b). Between fragmented ties and 'soul friendships': the crossborder social connections of young Romanians in London, Journal of Ethnic and Migration Studies, 39 (3), 353-372.

Moroșanu, L. and Fox, J. E. (2013). 'No smoke without fire': Strategies of coping with stigmatised migrant identities, Ethnicities, 13 (4), 438-456.

Nikolov, D. (2013). \#neochakvanite. [\#theunexpected]. 19 June 2013, available on the Webcafe [online], Retrieved from http://www.webcafe.bg/id_1245035277_ .

OECD. (2012). International Migration Outlook 2012. Paris: OECD Publishing. 
Però, D. (2008). Political engagement of Latin Americans in the UK: issues, strategies, and the public debate, Focaal- European Journal of Anthropology, 51, 73-90.

Pickering, M. (2001). Stereotyping: The Politics of Representation. Basingstoke: Palgrave.

Rolfe, H. et al. (2013). Potential Impacts on the UK of Future Migration from Bulgaria and Romania. Retrieved from the National Institute for Economic and Social Research (NIESR) website: http://www.niesr.ac.uk/publications/potential-impacts-uk-futuremigration-bulgaria-and-romania\#.UXMYUbU3v2o.

Ryan, L. (2010). Becoming Polish in London: negotiating ethnicity through migration, Social Identities: Journal for the Study of Race, Nation and Culture, 16 (3), 359- 376.

Ryan, L. \& Mulholland, J. (2014). Trading places: French highly skilled migrants negotiating mobility and emplacement in London, Journal of Ethnic and Migration Studies, 40 (4), 584- 600.

Salt, J. (1992). Migration Processes among the Highly Skilled in Europe, International Migration Review, 26 (2), 484- 505.

Seiter, E. (1986). Stereotypes and the media, Journal of Communication, spring, 14- 26. Smith, A. D. (1995). Nations and Nationalism in a Global Era. Cambridge: Polity Press.

Soodin, V. (2013). Crazed Bulgarian Who Beheaded Brit Gran is Found Guilty, The $\begin{array}{llll}\text { Sun } & \text { [online]. } & \text { Retrieved }\end{array}$ http://www.thesun.co.uk/sol/homepage/news/4808294/crazed-bulgarian-who-beheadedbrit-gran-in-tenerife-is-found-guilty.html.

$\begin{array}{llll}\text { The } & \text { Complete } & \text { University } & \text { Guide. }\end{array}$ http://www.thecompleteuniversityguide.co.uk/university-tuition-fees/going-touniversity-in-scotland/.

The Telegraph. (2013). Bulgarian Midwife Almost Injected New- Born Baby with Lethal Air Bubble, The Telegraph, [online]. Retrieved from http://www.telegraph.co.uk/health/healthnews/9853058/Bulgarian-midwife-almostinjected-new-born-baby-with-lethal-air-bubble.html.

Triandafyllidou, A. (2006). Nations, migrants and transnational identifications: an interactive approach to nationalism. In G. Delanty \& K. Kumar (eds.), The SAGE Handbook of Nations and Nationalism (pp. 285- 294). London: SAGE Publications. 
UKBA. (2011). Guidance for Nationals of Bulgaria and Romania on Obtaining Permission to Work in the UK. (BR 1 Guidance Notes, version 06/11). Retrieved from http://www.ukba.homeoffice.gov.uk/sitecontent/applicationforms/bulgariaromania/guid anceforbulgariaromania0408.

Wolfeil, N. (2009). Student Mobility from New to Old Member States in the European Union- Changing Patterns after $1^{\text {st }}$ of May 2004?, CMR Working Papers, 42 (100), 139. 
Notes:

${ }^{1}$ DANS is the Bulgarian abbreviation of the State Agency for National Security, which closely resembles the English verb 'to dance'.

${ }^{2}$ All participants are referred to by pseudonyms to preserve their anonymity.

${ }^{3}$ As EU citizens, Bulgarian students for tuition fees purposes are treated as home students in the UK. However, the Student Awards Agency for Scotland pays the tuition fees for only Scottish residents and non- UK EU citizens. As the fee waiver does not apply to English students, this paradoxically results in giving Bulgarians more rights than the English. For more information, please see the Complete University Guide, available at: http://www.thecompleteuniversityguide.co.uk/university-tuition-fees/going-to-university-in-scotland/. 
Appendix Error! Main Document Only. Participant Profiles

\begin{tabular}{|c|c|c|c|c|c|c|c|c|c|}
\hline No & Name & Sex & Age & Occupation & $\begin{array}{l}\text { Length of } \\
\text { stay in the } \\
\text { UK }\end{array}$ & $\begin{array}{l}\text { Level of } \\
\text { education }\end{array}$ & BG hometown & UK Location & $\begin{array}{l}\text { Interview } \\
\text { location }\end{array}$ \\
\hline 1 & Emanuela & $\mathrm{F}$ & 25 & YP & 2 years & Masters & Targovishte & East Midlands & $\begin{array}{l}\text { Researcher's } \\
\text { home }\end{array}$ \\
\hline 2 & Paula & $\mathrm{F}$ & 25 & YP & 4 years & Bachelors & Haskovo & London & Flight to $B G$ \\
\hline 3 & Kalina & $\mathrm{F}$ & 25 & YP & 6 years & Masters & Bourgas & $\begin{array}{l}\text { Southern } \\
\text { England }\end{array}$ & $\begin{array}{l}\text { Participant's } \\
\text { home }\end{array}$ \\
\hline 5 & Denitsa & $\mathrm{F}$ & 24 & $\mathrm{~S}$ & 5 years & Bachelors & Silistra & East Midlands & University café \\
\hline 6 & Vasil & $M$ & 23 & YP & 4 years & Bachelors & Sofia & East Midlands & Café \\
\hline
\end{tabular}




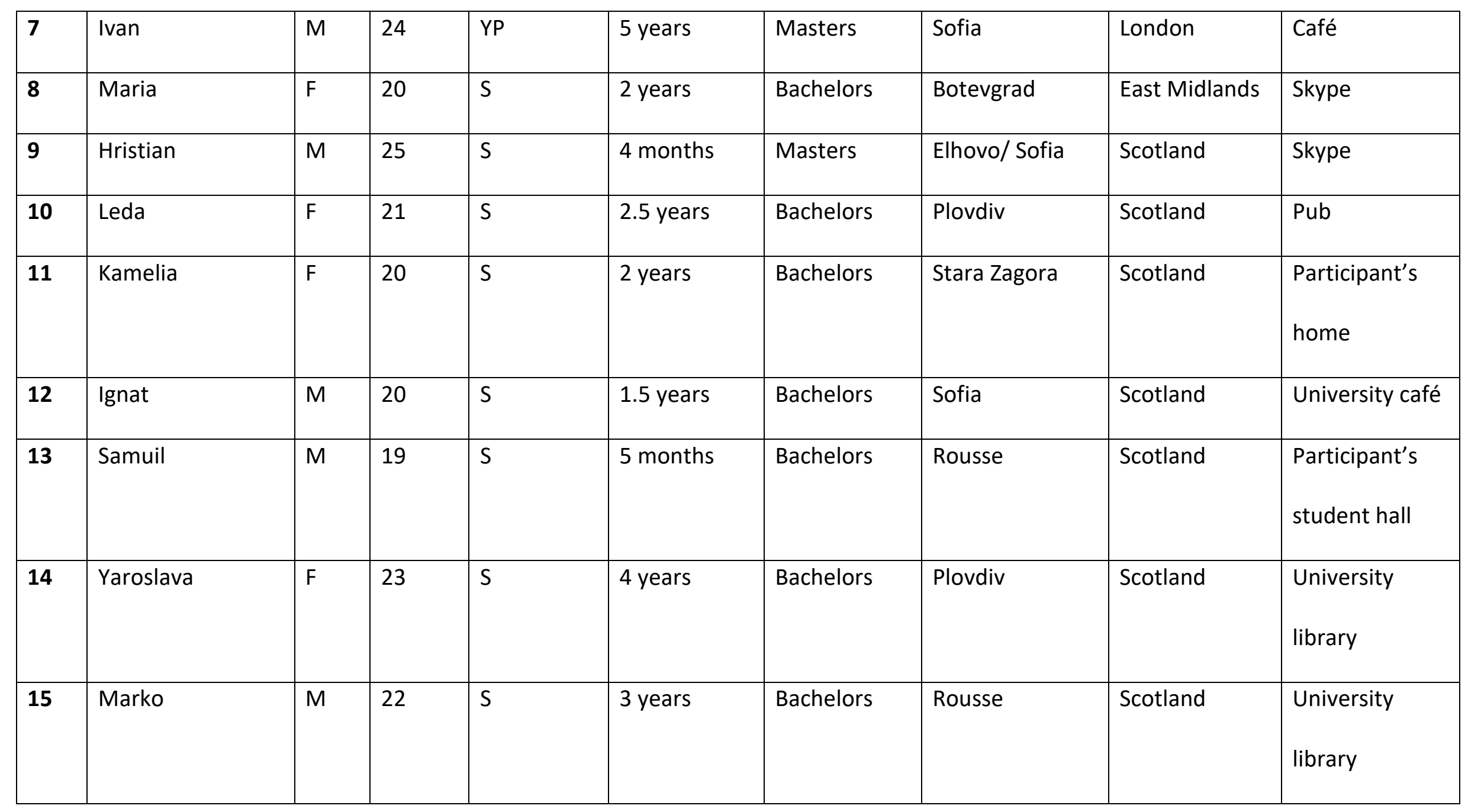




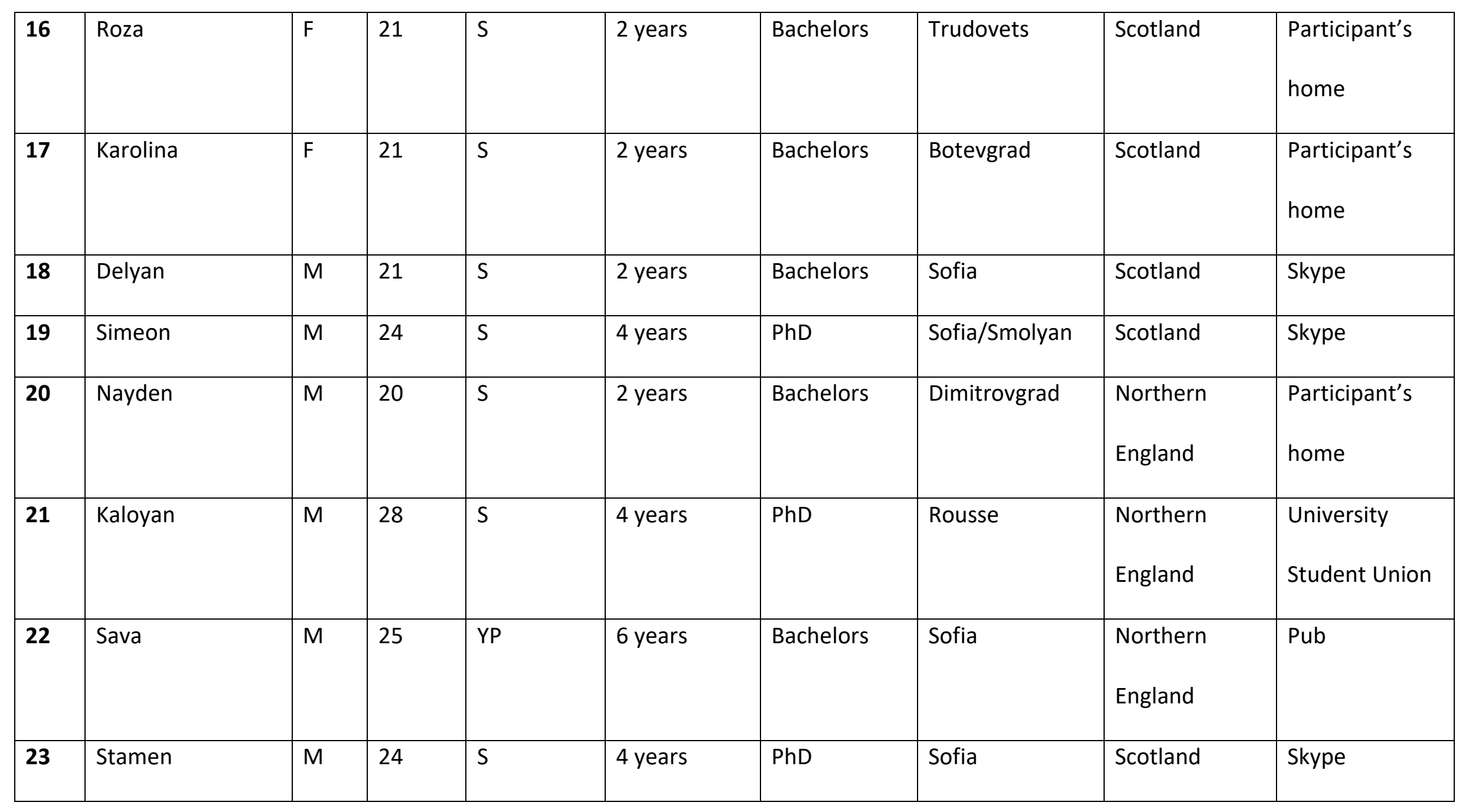




\begin{tabular}{|c|c|c|c|c|c|c|c|c|c|}
\hline 24 & Dessie & $\mathrm{F}$ & 23 & $\mathrm{YP}$ & 3.5 years & Bachelors & Nikolaevo & London & $\begin{array}{l}\text { Participant's } \\
\text { home }\end{array}$ \\
\hline 27 & Adrian & $M$ & 20 & $S$ & 1.5 years & Bachelors & Rousse & East Midlands & University café \\
\hline 28 & Kiril & $M$ & 19 & $S$ & 5 months & Bachelors & Bourgas & East Midlands & University café \\
\hline 29 & Natalia & $\mathrm{F}$ & 24 & YP & 4 years & Bachelors & Sofia & London & Café \\
\hline 32 & Teodora & $F$ & 32 & YP & 7 years & Masters & Knezha & London & Park \\
\hline 33 & Boyan & $M$ & 23 & YP & 4 years & Bachelors & Stara Zagora & $\begin{array}{l}\text { Southern } \\
\text { England }\end{array}$ & Café \\
\hline
\end{tabular}




\begin{tabular}{|l|l|l|l|l|l|l|l|l|l|}
\hline 34 & Ralitsa & F & 23 & YP & 4 years & Bachelors & Sofia & London \\
\hline 35 & Maggie & F & 29 & YP & 7 years & Masters & Sevlievo & Wales \\
\hline $\mathbf{3 6}$ & Nelly & F & 23 & S & 4 years & Bachelors & Sofia & Northern & Café \\
\hline $\mathbf{3 7}$ & Viktor & M & 25 & YP & 11 years & Bachelors & Bourgas & Wales & Skype \\
\hline
\end{tabular}

- NB1: Status - 'S' stands for 'student', whereas 'YP' stands for young professional

* NB2: Age and length of stay in the UK- the data provided is at the time of the interview 
